\title{
Welfare and spatial distribution of noise levels in swine nursery
}

\author{
Flavio A. Damasceno ${ }^{1}$, Carlos E. A. Oliveira ${ }^{1}$, Gabriel A. e S. Ferraz ${ }^{1}$, \\ João A. C. do Nascimento ${ }^{1}$, Jairo A. O. Saraz ${ }^{2} \&$ Leidimar F. Brandão ${ }^{3}$
}

${ }^{1}$ Universidade Federal de Lavras/Departamento de Engenharia. Lavras, MG, Brasil. E-mail: flavio.damasceno@deg.ufla.br (Corresponding author) ORCID: 0000-0002-8284-7496; carloseaoliveira@hotmail.com - ORCID: 0000-0003-1662-4750; gabriel.ferraz@deg.ufla.br - ORCID: 0000-0001-64032210; jacostadonascimento@gmail.com - ORCID: 0000-0001-5984-5997

${ }^{2}$ Universidad Nacional de Colombia/Facultad de Ciencias Agropecuarias. Medellín, Colômbia. E-mail: aosorio@unal.edu.co - ORCID: 0000-0002-4358-3600

${ }^{3}$ Universidade Federal de Ouro Preto/Departamento de Engenharia Civil. Ouro Preto, MG, Brasil. E-mail: leidimarbrandao@gmail.com - ORCID: 0000-00018429-7654

\begin{abstract}
The aim of this study was to evaluate the welfare and spatial distribution of noise levels in a swine nursery during the first three weeks of animal's life. The climatic conditions were evaluated through the dry-bulb temperature $\left(\mathrm{T}_{\mathrm{db}}\right)$, relative humidity $(\mathrm{RH})$ and black globe temperature and humidity index (BGHI) and allowed us to observe that the heating system influenced the conditions in the environment, and the use of the air conditioning system did not guarantee animal's comfort conditions. The analysis on the spatial distribution of noise levels was performed using geostatistics and demonstrated the occurrence of spatial variability inside the facilities. The highest frequencies of noise levels were concentrated between 60 and $70 \mathrm{~dB}$, and the highest noise values were observed near the fans. The mean BGHI values were below the thermal comfort range for piglets in all systems tested.
\end{abstract}

Key words: pig farming, thermal comfort, sound pressure, spatial variability

\section{Bem-estar e distribuição espacial do nível de ruído em maternidade de suínos}

RESUMO: Objetivou-se com este trabalho avaliar o bem-estar e a distribuição espacial dos níveis de ruído no interior de uma maternidade de suínos durante as três primeiras semanas de vida dos animais. A avaliação das condições climáticas, realizada através da temperatura de bulbo seco $\left(\mathrm{T}_{\mathrm{bs}}\right)$, umidade relativa (UR) e índice de temperatura do globo negro e umidade (ITGU), permitiu observar que o tipo de sistema de aquecimento influenciou as condições do ambiente, assim como a utilização do sistema de climatização não garantiu condições de conforto aos leitões. A análise da distribuição espacial dos níveis de ruído, realizada por meio da técnica de geoestatística, possibilitou verificar a ocorrência de variabilidade espacial no interior da instalação. As maiores frequências dos níveis de ruído concentram-se entre 60 e $70 \mathrm{~dB}$. Os valores médios de ITGU situaram-se fora da faixa de conforto térmico para os leitões em todos os sistemas testados.

Palavras-chave: suinocultura, conforto térmico, pressão sonora, variabilidade espacial 


\section{INTRODUCTION}

Swine production generally has high level of mechanization and control of operations within the husbandry environment, providing a low labor rate with intermittent routine, which allows for a reduced presence of handler inside the livestock facilities and several other functions outside the animal husbandry environment (Amare \& Endalew, 2016).

The livestock production environment was evaluated control at confined housing. The noise levels emitted by the swines have been studied by several researchers (Borges et al., 2010; Castro et al., 2013), who seek ways to establish sound patterns emitted by them according to the evaluated situations.

Even though the noise level inside the livestock facilities has received more attention from researchers, few studies evaluated climatic conditions and the effect on the spatial distribution of noise.

Environmental factors (air temperature, relative humidity, air speed, radiation, among others) have an influence on animal thermoregulation. Adverse climatic conditions are limiting to achieve maximum productivity, particularly in swine nursery during the first three weeks of animal's life, wherein sensitivity to heat is strengthened, thus using breath as heat dissipation mechanism to prevent internal heating. Thus, environmental monitoring is critical to making decisions on corrections or adjustments to be made in animal facilities, developing then an effective management to fix each issue raised. In order to understand the control of the environment generated by animal facility type, several computational tools can be used (fluid mechanics, Fuzzy logic, geostatistics, and others).

Geostatistical methods provide a set of techniques necessary to understand the apparent data randomness, but these may show spatial structure and thus establish a spatial dependence (Yamamoto \& Landim, 2013).

The aim of this study was to evaluate the welfare and spatial distribution of noise levels inside a swine nursery with different heating systems during the first three weeks of animal's life.

\section{Material And Methods}

The study was performed in the summer period of 2015 in a swine nursery of the Experimental Center of pig farming

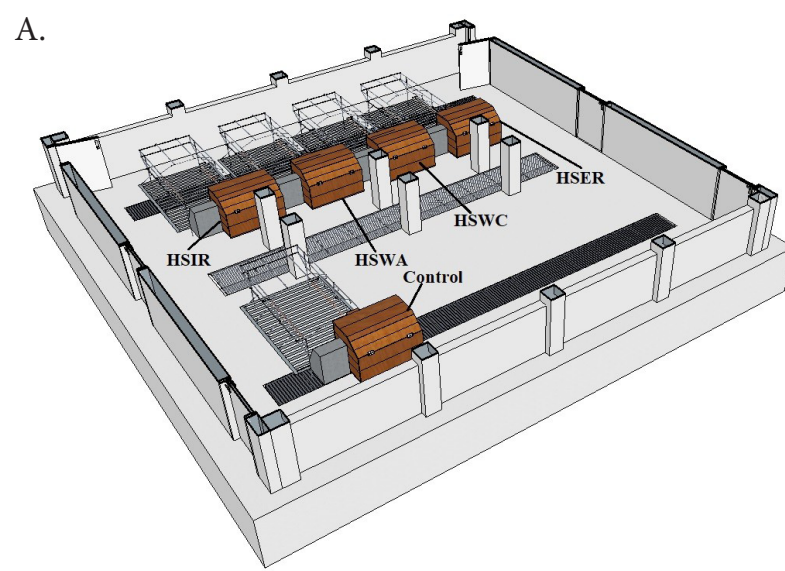
through innovative methods, non-invasive tools and welfare

of the Federal University of Lavras, in Lavras, MG, Brazil (21 ${ }^{\circ}$ $14^{\prime} \mathrm{S}, 45^{\circ} 00^{\prime} \mathrm{W}, 918.84 \mathrm{~m}$ altitude, with average temperature of $19.4^{\circ} \mathrm{C}$, and average annual rainfall of $1529.7 \mathrm{~mm}$ ).

The nursery used in this experiment showed the following building characteristics: dimensions of $8.26 \mathrm{~m}$ width and $8.40 \mathrm{~m}$ length, ceiling height of $2.15 \mathrm{~m}$, gable roof, wood structure, and covered with ceramic tiles. Five bays ( $1.80 \mathrm{~m}$ length and $1.35 \mathrm{~m}$ width) attached to wooden creep feeder (with $1.00 \mathrm{~m}$ length and $0.68 \mathrm{~m}$ width) were installed inside the nursery. A ventilation/nebulization system was installed inside the nursery and controlled by a timer, operating at certain times during the hottest periods of the day (11 a.m. to 5 p.m.), according to the management carried out by the owner.

In the evaluated facility, four different heating systems were installed: a creep shelter with a) $250 \mathrm{~W}$ infrared light (HSIR); b) concrete floor heated by hot water pipes constructed with alternative materials (HSWA); c) concrete floor heated by conventional hot water pipes (HSWC); and d) concrete floor heated through heating cable (HSER), that consisting of a series resistance heating cable and a power lead for connection to the electric power supply (127 VA). The control treatment was HSIR. More details can be observed in Sousa et al. (2015). Figure 1A shows the distribution of the systems.

The concrete floor heated by hot water pipes constructed with alternative materials (HSWA) was built with PVC pipes and connections ( $1 / 2$ " diameter), PET bottles and milk cartons (Tetra Pak ${ }^{\circledast}$ ). In this prototype, the PET bottles were intended to protect the interior of the collector from external interference, such as winds and changes in air temperature. Sixty transparent 2-L bottles of polyethylene terephthalate (PET) were used. For this, the cap and bottom of each bottle were removed. Tetra $\mathrm{Pak}^{\circledast}$ boxes were opened at the top and bottom, leaving them flattened.

The concrete floor heated by conventional hot water pipes (HSWC) had a solar collector of glass plate, made of extruded aluminum, with internal fins painted in matte black to absorb radiation and transfer it to internal piping. The thermal reservoir had components of internal cylinder, pipes manufactured with stainless steel, and rigid expanded polyurethane.

The piglets used in this study originated from sows from the same birth order and were equalized with the objective of

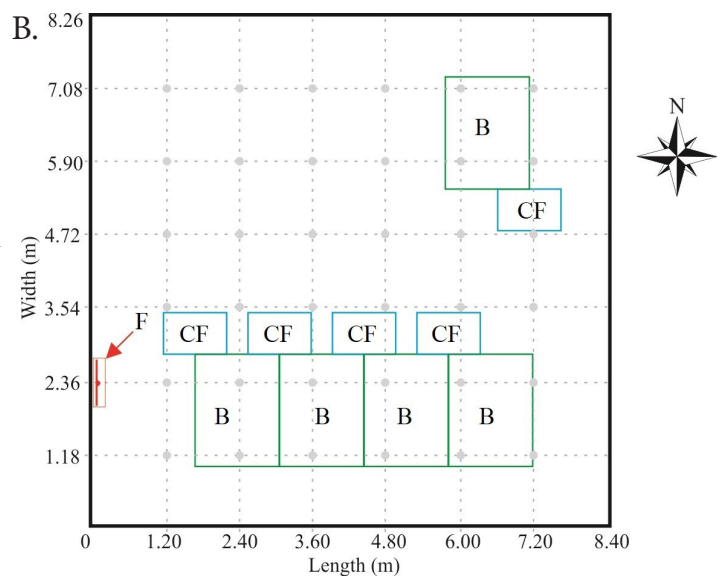

${ }^{*} \mathrm{~F}$ - Fan/air conditioner; CF - Creep feeder and B - Bay; For details of HSIR, HSWA, HSWC, HSER and control see Material and Methods

Figure 1. Schematic drawing of the distribution of different heating systems $(A)$, and $(B)^{*}$ collection points of noise level inside the facility 
eliminating interference factors, maternal ability, number of piglets/litter, etc. Each bay had an average of 10 piglets that were reassembled according to weight and number of animals after birth, so that all the studied shelters remained with a fixed number between 8 and 12 piglets.

Throughout the study, the environmental variables were monitored in the creep shelter, in both internal and external nursery environments, through automated sensor/recorder systems. The variables used to evaluate the thermal environment were dry-bulb temperature $\left(\mathrm{T}_{\mathrm{db}}\right)$, relative humidity $(\mathrm{RH})$, dew point temperature $\left(\mathrm{T}_{\mathrm{dp}}\right)$, black globe temperature $\left(\mathrm{T}_{\mathrm{bg}}\right)$, and air velocity $\left(\mathrm{V}_{\text {air }}\right)$. These environmental variables were recorded every $10 \mathrm{~min}, 24 \mathrm{~h} \mathrm{~d}^{-1}$, during the first 21 days of piglet's life, at a point allocated inside the creep.

BGHI was calculated through the equation developed by Buffington et al. (1981) based on the data from dew point $\left(\mathrm{T}_{\mathrm{dp}}\right)$ and black globe temperature $\left(\mathrm{T}_{\mathrm{bg}}\right)$.

Infrared laser digital thermometer (Instrutemp ${ }^{\circledR}$, mod. ITTI 550 and precision $\pm 2.0^{\circ} \mathrm{C}$ ) was used to measure the temperature of the floor surface, which was collected at nine equidistant points.

Regarding noise levels, the internal nursery area was divided into a mesh composed of 36 equidistant points. During the entire study period, data from sound pressure levels $(\mathrm{dB})$ were collected, using a digital sound level meter (Instrutemp ${ }^{\oplus}$, model ITDEC4020, 30 to $130 \mathrm{~dB}(\mathrm{~A})$, and accuracy $\pm 1.0 \mathrm{~dB}$ ). Measurements were performed at regular intervals of three days throughout the nursery cycle, manually and always in the morning (9 to 11 a.m.) and afternoon (2 to 4 p.m.) periods. For each point, three collections were performed, using the arithmetic average for the sample data composition. The noise levels were collected at $1.00 \mathrm{~m}$ height, which is compatible with the height of the geometric center of adult animals inside each cage. The mesh collection of sound pressure levels is shown in Figure 1B.

The environmental variables $\left(T_{d b}, R H\right.$ and $\left.B G H I\right)$ were defined using a randomized complete block design, in a splitplot design, whereby the plots are the heating systems (HSIR, HSWA, HSWC, HSER, and outside), and the subplots are the evaluated periods (morning and afternoon), according to the following mathematical model:

$$
\mathrm{Y}_{\mathrm{ijk}}=\mu+\mathrm{B}_{\mathrm{j}}+\mathrm{M}_{\mathrm{i}}+\varepsilon_{\mathrm{ij}}+\mathrm{H}_{\mathrm{k}}+\theta_{\mathrm{jk}}+\mathrm{MH}_{\mathrm{ik}}+\delta_{\mathrm{ijk}}
$$

where:

$\mathrm{Y}_{\mathrm{ijk}}$ - effect of the heating system i in the period $\mathrm{j}$, in the replicate $\mathrm{k}$;

$\mu \quad$ - overall average;

$\mathrm{B}_{\mathrm{j}} \quad$ - effect of positioning in the bay;

$M_{i} \quad$ - effect of the heating system $\mathrm{i}$;

$\varepsilon_{\mathrm{ij}} \quad$ - random error a;

$\mathrm{H}_{\mathrm{k}} \quad$ - effect of period $\mathrm{k}$;

$\theta_{\mathrm{j} k} \quad$ random error b;

$\mathrm{MH}_{\mathrm{ik}}$ - effect of the interaction of construction material i with collection time $\mathrm{k}$; and,

$\delta_{\mathrm{ijk}} \quad$ random error $\mathrm{c}$.

The geostatistical technique was used to verify the spatial distribution of noise levels inside the animal facility, to predict the noise levels, and to verify dependence among the collection points. The geostatistical analysis was performed using the R Development Core Team computer system, through the geoR library (Ribeiro Junior \& Diggle, 2001). The spatial dependence of noise levels inside the facility during the nursery phase was verified by fitting semivariogram and interpolation by ordinary kriging. The semivariogram was estimated through the equation suggested by Bachmaier \& Backers (2011). The spatial dependence degree (SPD) of noise level emitted by swine inside the facility was determined by the ratio between the nugget effect $\left(\mathrm{C}_{0}\right)$ and the sill $\left(\mathrm{C}_{0}+\mathrm{C}_{1}\right)$, multiplied by 100 . For the SPD analysis, the classification of Seidel \& Oliveira (2016) was used, where semivariograms with strong spatial dependence show nugget effect lower than $25 \%$ of sill, moderate between 25 and $75 \%$, and weak when higher than $75 \%$. The semivariogram was fitted by the ordinary least squares (OLS) and the restricted maximum likelihood (REML) methods.

For the spatialization of noise levels inside the facility, the data interpolation was performed by ordinary kriging. This method was used to predict noise levels in non-sampled locations inside the facility. Based on these data, response surface maps were generated using the SigmaPlot ${ }^{\circ}$ software, version 12.0. Comparisons among the groups were performed using the Tukey test on the generalized linear model (GLM) in the SAS statistical software version 9.3 (SAS Institute, 2010), at 0.05 confidence level.

\section{RESUlts AND Discussion}

The results of the environmental characterization obtained for the morning and afternoon periods are shown in Table 1. As can be observed, some climatic elements of the environment were influenced by the heating system ( $p<0.05$, Tukey test), and $\mathrm{T}_{\mathrm{db}}$ and $\mathrm{RH}$ inside the facilities were mostly higher in the cage with HSWA treatment, while BGHI assumed a higher value ( $\mathrm{p}<0.05$, Tukey test) on days 4 and 8 in the HSIR treatment. There was no significant difference $(\mathrm{p}>0.05)$ between average values of BGHI for the treatments with the different systems tested on days 12, 16, and 20 .

There was a significant difference ( $\mathrm{p}<0.05$, Tukey test) between $\mathrm{T}_{\mathrm{db}}$ and $\mathrm{RH}$ in the bays with different heating systems, since these behaved differently throughout the cycle. For most of the evaluated days, the HSWA system showed mean values of $\mathrm{T}_{\mathrm{db}}$ higher than the other ones. The HSWA and HSER systems showed higher mean values of $\mathrm{RH}$ along most of the days evaluated in the study period. These higher values of RH must have been due to the worse ventilation occurred inside these two bays, which generated accumulation of greater humidity inside the bays.

Both in the morning and in the afternoon period, the mean value of $\mathrm{T}_{\mathrm{db}}$ in the bays was not adequate for thermal comfort for the animals in any heating system. In the afternoon, the mean values of $T_{d b}$ were suitable for piglets on the days in the second and third weeks. 
Table 1. Values of dry-bulb temperature $\left(\mathrm{T}_{\mathrm{db}},{ }^{\circ} \mathrm{C}\right)$, relative humidity $(\mathrm{RH}, \%)$ and black globe humidity index (BGHI), in creep and bay for swines with different heating systems during the morning and afternoon periods

\begin{tabular}{|c|c|c|c|c|c|c|}
\hline \multicolumn{7}{|c|}{ Time } \\
\hline \multirow{2}{*}{ System } & \multicolumn{3}{|c|}{ Morning } & \multicolumn{3}{|c|}{ Afternoon } \\
\hline & $\overline{T_{d b}\left({ }^{\circ} \mathbf{C}\right)}$ & RH (\%) & BGHI & $\mathrm{T}_{\mathrm{db}}\left({ }^{\circ} \mathrm{C}\right)$ & RH (\%) & BGHI \\
\hline \multicolumn{7}{|c|}{ Day 1} \\
\hline HSIR & $23.04 \pm 0.77 b$ & $85.09 \pm 2.14 a b$ & $71.23 \pm 0.99 b$ & $25.36 \pm 0.50 c$ & $79.43 \pm 1.75 a$ & $74.29 \pm 0.58 b$ \\
\hline HSWA & $23.62 \pm 0.71 \mathrm{a}$ & $85.50 \pm 2.01 \mathrm{a}$ & $71.67 \pm 0.94 b$ & $26.03 \pm 0.49 b$ & $79.53 \pm 1.61 \mathrm{a}$ & $74.80 \pm 0.64 b$ \\
\hline HSWC & $23.10 \pm 0.66 b$ & $84.08 \pm 1.93 c$ & $71.06 \pm 0.74 b$ & $25.43 \pm 0.48 c$ & $78.22 \pm 1.77 b$ & $73.81 \pm 0.60 b$ \\
\hline HSER & $22.89 \pm 0.65 b$ & $85.03 \pm 1.83 a b$ & $71.23 \pm 0.81 b$ & $25.05 \pm 0.46 d$ & $79.64 \pm 1.69 \mathrm{a}$ & $74.06 \pm 0.59 b$ \\
\hline Outside & $23.03 \pm 1.53 b$ & $84.60 \pm 5.41 \mathrm{cb}$ & $77.92 \pm 4.85 a$ & $26.80 \pm 1.03 a$ & $72.67 \pm 3.13 c$ & $86.10 \pm 4.78 a$ \\
\hline C.V. (\%) & 1.72 & 1.90 & 2.50 & 1.44 & 1.31 & 2.70 \\
\hline \multicolumn{7}{|c|}{ Day 4} \\
\hline HSIR & $22.16 \pm 0.87 b$ & $86.52 \pm 1.32 \mathrm{a}$ & $80.20 \pm 1.07 \mathrm{a}$ & $22.80 \pm 0.71 c$ & $86.46 \pm 2.64 \mathrm{a}$ & $81.74 \pm 0.61 \mathrm{a}$ \\
\hline HSWA & $22.93 \pm 1.07 \mathrm{a}$ & $86.57 \pm 1.77 \mathrm{a}$ & $74.26 \pm 0.66 b$ & $23.75 \pm 0.79 a$ & $85.81 \pm 2.44 \mathrm{a}$ & $73.16 \pm 0.81 c$ \\
\hline HSWC & $22.38 \pm 1.06 b$ & $85.68 \pm 2.08 a b$ & $72.85 \pm 1.19 b$ & $23.23 \pm 0.83 b$ & $84.62 \pm 2.51 b$ & $73.71 \pm 0.61 c$ \\
\hline HSER & $22.16 \pm 0.91 b$ & $86.60 \pm 1.54 \mathrm{a}$ & $70.73 \pm 1.33 b$ & $22.86 \pm 0.77 c$ & $86.23 \pm 2.46 \mathrm{a}$ & $72.88 \pm 0.70 \mathrm{c}$ \\
\hline Outside & $22.98 \pm 2.38 \mathrm{a}$ & $84.68 \pm 6.55 b$ & $79.42 \pm 6.06 a$ & $22.88 \pm 1.83 c$ & $83.79 \pm 5.39 b$ & $75.59 \pm 5.76 b$ \\
\hline C.V. (\%) & 2.99 & 2.93 & 3.49 & 2.20 & 1.82 & 2.98 \\
\hline \multicolumn{7}{|c|}{ Day 8} \\
\hline HSIR & $24.72 \pm 0.88 b$ & $81.88 \pm 2.94 c$ & $82.87 \pm 0.67 a$ & $27.92 \pm 0.78 \mathrm{e}$ & $70.45 \pm 3.26 c$ & $85.58 \pm 0.75 b$ \\
\hline HSWA & $25.11 \pm 1.00 \mathrm{a}$ & $83.08 \pm 3.25 b$ & $74.96 \pm 0.85 b c$ & $28.68 \pm 0.83 b$ & $71.03 \pm 3.57 b$ & $77.66 \pm 0.94 d$ \\
\hline HSWC & $24.54 \pm 1.02 b$ & $81.51 \pm 3.25 c$ & $76.11 \pm 0.91 b$ & $28.27 \pm 0.82 c$ & $69.79 \pm 3.56 d$ & $78.32 \pm 0.65 c$ \\
\hline HSER & $24.19 \pm 1.10 c$ & $82.88 \pm 3.35 b$ & $74.59 \pm 1.34 c$ & $28.13 \pm 0.85 d$ & $70.25 \pm 4.00 \mathrm{~cd}$ & $78.02 \pm 0.63 \mathrm{~cd}$ \\
\hline Outside & $24.22 \pm 2.01 c$ & $90.68 \pm 3.67 \mathrm{a}$ & $83.45 \pm 6.11 \mathrm{a}$ & $30.05 \pm 0.94 a$ & $81.01 \pm 2.74 \mathrm{a}$ & $97.47 \pm 2.72 a$ \\
\hline C.V. (\%) & 1.96 & 0.85 & 3.34 & 0.47 & 1.35 & 1.32 \\
\hline \multicolumn{7}{|c|}{ Day 12} \\
\hline HSIR & $23.50 \pm 0.95 b$ & $85.67 \pm 2.51 b$ & $72.45 \pm 1.16 b$ & $27.14 \pm 1.20 \mathrm{c}$ & $74.44 \pm 3.69 b c$ & $76.85 \pm 1.42 b$ \\
\hline HSWA & $24.10 \pm 1.09 a$ & $85.72 \pm 2.92 b$ & $71.81 \pm 1.57 b$ & $27.86 \pm 1.11 b$ & $74.85 \pm 2.98 b$ & $76.84 \pm 1.41 b$ \\
\hline HSWC & $23.67 \pm 1.18 b$ & $84.01 \pm 3.17 c$ & $72.38 \pm 1.87 b$ & $27.25 \pm 1.12 c$ & $73.72 \pm 3.08 d$ & $77.34 \pm 1.30 b$ \\
\hline HSER & $23.72 \pm 1.07 b$ & $84.07 \pm 2.91 \mathrm{c}$ & $73.02 \pm 1.50 b$ & $27.16 \pm 1.15 c$ & $74.01 \pm 2.94 \mathrm{~cd}$ & $77.44 \pm 1.41 b$ \\
\hline Outside & $23.46 \pm 2.26 b$ & $95.31 \pm 2.59 \mathrm{a}$ & $82.67 \pm 7.48 \mathrm{a}$ & $29.44 \pm 1.62 \mathrm{a}$ & $90.42 \pm 1.21 \mathrm{a}$ & $96.35 \pm 3.55 a$ \\
\hline C.V. (\%) & 2.49 & 0.90 & 3.67 & 0.91 & 1.56 & 1.42 \\
\hline \multicolumn{7}{|c|}{ Day 16} \\
\hline HSIR & $24.05 \pm 1.05 b$ & $83.78 \pm 2.53 c$ & $73.38 \pm 1.32 b$ & $27.49 \pm 0.77 \mathrm{a}$ & $71.84 \pm 3.45 d$ & $77.37 \pm 0.80 b c$ \\
\hline HSWA & $24.64 \pm 1.06 a$ & $84.61 \pm 2.55 b$ & $73.28 \pm 1.20 b$ & $28.11 \pm 0.84 b$ & $73.03 \pm 3.50 b$ & $77.23 \pm 0.94 c$ \\
\hline HSWC & $24.10 \pm 1.01 b$ & $83.50 \pm 2.38 c$ & $73.07 \pm 1.54 b$ & $27.42 \pm 0.81 d$ & $72.38 \pm 3.35 \mathrm{~cd}$ & $77.38 \pm 0.83 b c$ \\
\hline HSER & $24.16 \pm 0.94 b$ & $83.49 \pm 2.14 c$ & $73.68 \pm 1.29 b$ & $27.32 \pm 0.78 c$ & $72.79 \pm 3.40 b c$ & $77.67 \pm 0.87 b$ \\
\hline Outside & $24.77 \pm 2.11 \mathrm{a}$ & $96.04 \pm 2.12 \mathrm{a}$ & $83.35 \pm 4.94 a$ & $29.06 \pm 0.73 a$ & $90.21 \pm 1.85 a$ & $92.97 \pm 2.07 \mathrm{a}$ \\
\hline C.V. (\%) & 2.26 & 0.64 & 2.27 & 0.62 & 1.31 & 0.99 \\
\hline \multicolumn{7}{|c|}{ Day 20} \\
\hline HSIR & $24.12 \pm 0.56 b$ & $86.67 \pm 2.06 b$ & $73.52 \pm 0.84 b$ & $27.06 \pm 0.76 c$ & $75.65 \pm 3.27 c$ & $77.11 \pm 0.95 b$ \\
\hline HSWA & $24.50 \pm 0.67 a$ & $87.82 \pm 2.04 a b$ & $72.97 \pm 0.83 b$ & $27.69 \pm 0.80 b$ & $76.79 \pm 3.01 b$ & $76.91 \pm 1.01 b$ \\
\hline HSWC & $23.84 \pm 0.73 b$ & $86.69 \pm 2.09 b$ & $72.92 \pm 1.01 b$ & $26.96 \pm 0.73 \mathrm{~cd}$ & $76.68 \pm 2.76 b$ & $77.36 \pm 1.14 b$ \\
\hline HSER & $23.78 \pm 0.73 b$ & $87.23 \pm 2.33 a b$ & $73.27 \pm 1.09 b$ & $26.91 \pm 0.68 d$ & $77.81 \pm 2.51 \mathrm{a}$ & $77.47 \pm 0.95 b$ \\
\hline Outside & $23.88 \pm 2.06 b$ & $88.59 \pm 7.05 a$ & $78.51 \pm 5.55 a$ & $29.20 \pm 0.92 a$ & $68.18 \pm 3.57 d$ & $90.32 \pm 2.84 \mathrm{a}$ \\
\hline C.V. (\%) & 2.69 & 2.96 & 2.86 & 0.75 & 1.57 & 1.43 \\
\hline
\end{tabular}

Means followed by the same letters in the column do not differ among themselves by Tukey test at 0.05 probability. Number of variables (n) evaluated by period $=252$. For details of heating systems see Material and Methods

It was observed that in all tested systems, the RH averaged between 60 and $80 \%$ higher than the comfort range for swines, as stated by Cecchin et al. (2017), especially in the morning. The sow's ability to dissipate heat can be reduced by high values of $\mathrm{T}_{\mathrm{db}}$ associated with high $\mathrm{RH}$, since saturated air compromises the latent heat loss by the respiratory system, providing a more stressful environment.

In all tested heating systems, mean values of BGHI can be considered comfortable for sows in the morning on the first evaluated day. On the other hand, the mean values of BGHI were distanced from the ideal (72) in the other periods and days evaluated, as suggested by Budiño et al. (2014).

Table 2 shows the values of mean, median, standard deviation $(\sigma)$, coefficient of variation (CV), kurtosis (Curt), asymmetry (Ass.), Maximum value (Max.), and minimum value (Min.) of the noise level, in $\mathrm{dB}(\mathrm{A})$, within the maternity unit during the evaluation period.
The mean noise levels within the maternity bay with different heating systems were in the 54.67 and $65.72 \mathrm{~dB}(\mathrm{~A})$ in the morning, and 53.77 and $67.92 \mathrm{~dB}(\mathrm{~A})$, in the afternoon (Table 2). Most of the collection days, the semivariograms were adjusted to the spherical model, differing only on days 16 (morning) and 8 (afternoon), whose semivariogram was adjusted to the Gaussian Model (Table 3). The difference greater than almost $1.0 \mathrm{~dB}(\mathrm{~A})$ between the minimum and maximum values recorded inside the maternity unit shows the non-homogeneity of the data in the direction of the length of each cage and may be an indication of spatial dependence between the points of record. Despite the occurrence of some asymmetric distributions, the mean and median values of the studied noise levels are not close, showing that the data show a marked asymmetry. According to Little \& Hills (1978), when the value of the mean, median and fashion are not similar, the data do not show or approach the normal distribution. 
Table 2. Values of mean, median, standard deviation $(\sigma)$, coefficient of variation (CV), curtose (Curt), asymmetry (Ass.), minimum value (Min.), and maximum value (Max.) noise, in $\mathrm{dB}(\mathrm{A})$, within the maternity center during the evaluated days, during the morning and afternoon periods

\begin{tabular}{|c|c|c|c|c|c|c|c|c|}
\hline Time & Mean & Median & $\sigma$ & CV & Curt & Ass. & Min. & Max. \\
\hline \multicolumn{9}{|c|}{ Morning } \\
\hline 1 & 64.89 & 64.38 & 1.751 & 0.027 & -0.532 & 0.695 & 61.83 & 69.33 \\
\hline 4 & 54.78 & 54.70 & 2.883 & 0.053 & -0.750 & -0.054 & 48.80 & 60.73 \\
\hline 8 & 65.52 & 65.78 & 1.556 & 0.024 & -1.161 & -0.089 & 61.83 & 69.10 \\
\hline 12 & 54.67 & 54.38 & 1.147 & 0.021 & -1.305 & 0.242 & 52.57 & 57.10 \\
\hline 16 & 65.75 & 65.63 & 1.013 & 0.015 & -0.858 & 0.227 & 63.77 & 67.83 \\
\hline 20 & 57.33 & 57.35 & 0.909 & 0.016 & -0.642 & -0.067 & 55.27 & 59.53 \\
\hline \multicolumn{9}{|c|}{ Afternoon } \\
\hline 1 & 64.62 & 64.35 & 1.599 & 0.025 & -0.776 & 0.225 & 61.63 & 68.40 \\
\hline 4 & 53.77 & 53.58 & 1.627 & 0.030 & 0.037 & 0.711 & 50.73 & 59.13 \\
\hline 8 & 65.63 & 65.60 & 1.229 & 0.019 & -1.498 & 0.042 & 63.60 & 67.63 \\
\hline 12 & 60.39 & 60.15 & 1.607 & 0.027 & -1.262 & 0.251 & 57.60 & 63.57 \\
\hline 16 & 67.92 & 67.68 & 1.196 & 0.018 & -0.757 & 0.495 & 65.77 & 70.80 \\
\hline 20 & 63.62 & 63.66 & 0.987 & 0.016 & -0.728 & -0.229 & 61.33 & 65.57 \\
\hline
\end{tabular}

Table 3. Method, model and estimated parameters of the experimental semivariogram for noise level inside the nursery throughout the evaluation period during the morning and afternoon

\begin{tabular}{|c|c|c|c|c|c|c|c|c|c|c|c|}
\hline Time & Method & Model & $\mathbf{C}_{0}$ & $\mathbf{G}_{1}$ & $\mathbf{C}_{0}+\mathbf{C}_{1}$ & a & SPD & ME & $\mathbf{S D}_{\mathrm{m}}$ & RE & SDR \\
\hline \multicolumn{12}{|c|}{ Morning } \\
\hline 1 & OLS & Spherical & 0.000 & 5.236 & 5.236 & 7.787 & 0.00 & -0.013 & 0.918 & -0.006 & 0.919 \\
\hline 4 & OLS & Spherical & 0.000 & 13.27 & 13.272 & 5.536 & 0.00 & -0.039 & 1.235 & -0.009 & 0.638 \\
\hline 8 & REML & Spherical & 0.305 & 3.400 & 3.705 & 5.671 & 8.23 & -0.026 & 1.167 & -0.010 & 1.010 \\
\hline 12 & REML & Spherical & 0.098 & 1.338 & 1.435 & 6.633 & 6.82 & -0.016 & 0.684 & -0.011 & 1.017 \\
\hline 16 & OLS & Gaussian & 0.033 & 2.029 & 2.062 & 3.628 & 1.60 & -0.014 & 0.341 & -0.010 & 0.544 \\
\hline 20 & REML & Spherical & 0.009 & 1.138 & 1.147 & 5.010 & 0.76 & -0.018 & 0.636 & -0.014 & 1.031 \\
\hline \multicolumn{12}{|c|}{ Afternoon } \\
\hline 1 & REML & Spherical & 0.000 & 4.480 & 4.480 & 6.706 & 0.00 & -0.033 & 1.027 & -0.015 & 1.001 \\
\hline 4 & REML & Spherical & 0.770 & 4.050 & 4.820 & 5.596 & 15.98 & -0.026 & 1.453 & -0.008 & 1.005 \\
\hline 8 & REML & Gaussian & 0.251 & 2.760 & 3.011 & 4.745 & 8.34 & -0.019 & 0.550 & -0.016 & 0.957 \\
\hline 12 & REML & Spherical & 0.000 & 3.164 & 3.164 & 8.401 & 0.00 & -0.028 & 0.789 & -0.017 & 1.006 \\
\hline 16 & REML & Spherical & 0.000 & 1.257 & 1.257 & 3.640 & 0.00 & -0.018 & 0.700 & -0.011 & 0.915 \\
\hline 20 & REML & Spherical & 0.000 & 1.182 & 1.182 & 5.856 & 0.00 & -0.033 & 0.577 & -0.027 & 0.977 \\
\hline
\end{tabular}

$\mathrm{C}_{0}$ - Nugget effect; $\mathrm{C}_{1}$ - Structural variance; $\mathrm{C}_{0}+\mathrm{C}_{1}$. Sill; a - Range; SPD - Spatial dependence degree; ME - Mean error; $\mathrm{SD}_{\mathrm{m}}$. Standard deviation of mean error; RE - Reduced error; SDR Standard deviation of reduced error. Number of variables $(n)$ evaluated by period $=972$

This may be an indication that measures of central tendency are dominated by atypical values in the distribution (Seidel \& Oliveira, 2016). According to Isaaks \& Srivastava (1989) more important than the normality of the data is the occurrence of the proportional effect in which the mean and the variance of the data are not constant in the study area and this fact did not occur, since semivariograms presented well defined levels.

According to the classification suggested by Seidel \& Oliveira (2016) for SPD, a strong spatial dependence was observed among the collection points for all the days in which acquisitions were made (Table 3). By analyzing the range, which refers to the spatial extent on which the variable is correlated, for all the days in which noise data were sampled, the points were correlated with other points at considerable distances. The highest range values referred to days 1 (morning) and 12 (afternoon), with a ranges of 7.787 and $8.401 \mathrm{~m}$, respectively.

Based on the collected data and through interpolation by ordinary kriging, the noise levels were predicted throughout the facility, and distribution maps were generated (in $\mathrm{dB}$ ) for the evaluated days when the animals remained in the facility for morning and afternoon periods (Figure 2).

Based on Figure 2, a great variability of the noise level were observed inside the animal facility during all evaluated days. Mean sound pressure levels with a range below $10.0 \mathrm{~dB}$ were verified. Moreover, it can be noted that higher values of sound pressure levels were observed in the facilities with presence of animals in the bays. This is because the piglets were suckling or interacting during most of the collection period, concentrating the noise level in the vicinities.

The analysis of Figure 2 also allowed suggesting that some places showed higher average sound pressure levels during the evaluated period, especially the places where the bays were located and near the air conditioner. Due to the high temperatures recorded in the period, the air conditioner was turned on in most of the evaluated days, seeking to provide favorable thermal comfort conditions for the animals.

The Tukey test clearly evidenced $(\mathrm{p} \leq 0.05)$ that noise intensities between collection periods (morning and afternoon) are different (Figure 3 ), since the noise intensity variation was higher in the afternoon $( \pm 5.24 \mathrm{~dB})$. This situation may have occurred due to the greater need to maintain the thermal environment in the comfort zone inside the sheds, being necessary to activate the nursery cooling system.

Baracho et al. (2008) evaluated the seasonality of the acoustic environment in swine nurseries and observed that the noise levels in the facility were not influenced by season of the year. However, the authors observed oscillations of these levels during the day, which corroborate with the results found in the studies performed by Castro et al. (2013), when 

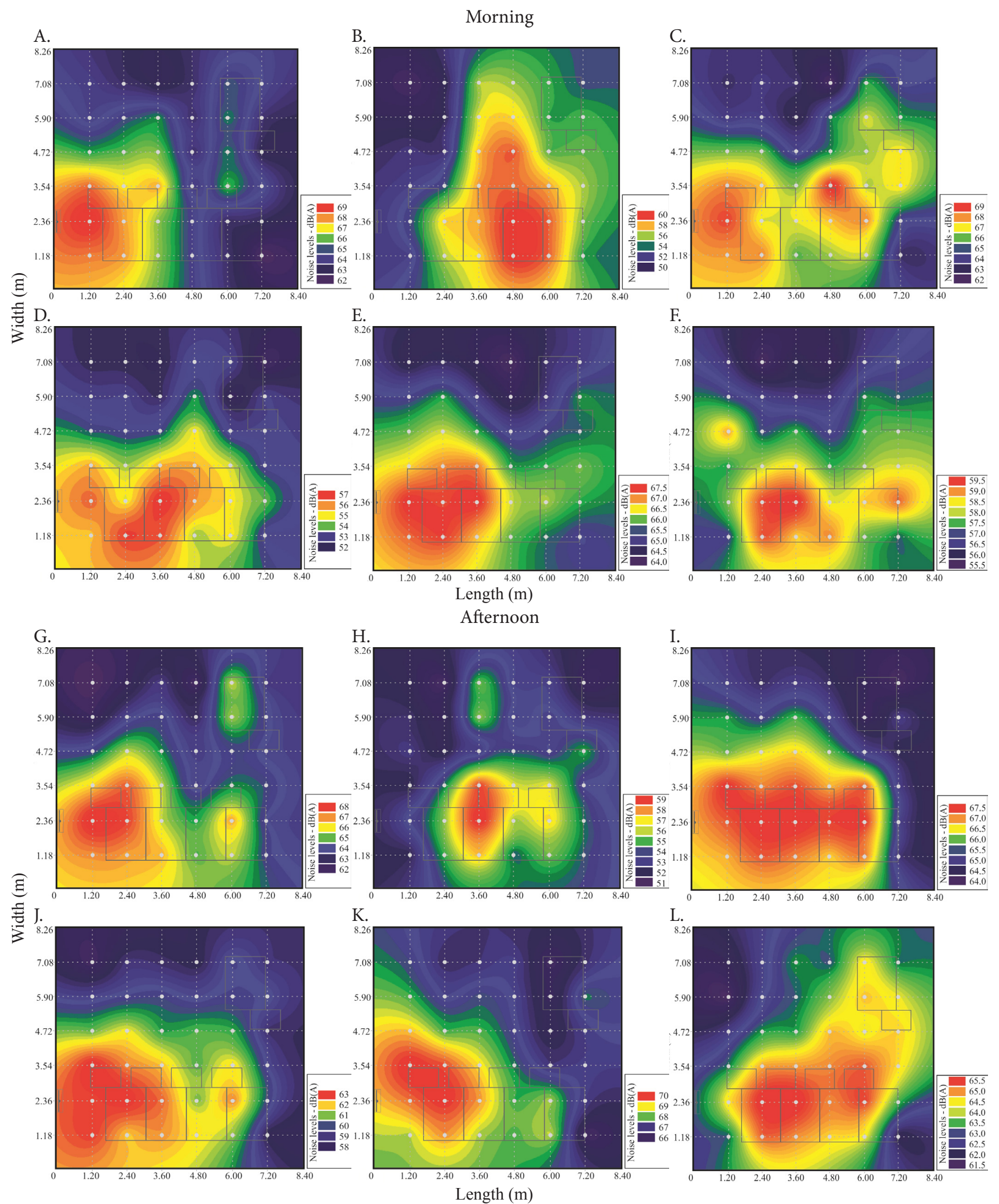

Figure 2. Spatial distribution of the average noise level in the morning and afternoon for days $1,4,8,12,16$, and 20 , respectively

evaluated the thermal environment and noise in nursery cells for swines with masonry partitions and slate rocks.

Figure 4 shows the frequencies of noise levels inside the swine nursery during the morning and afternoon periods. During the evaluated days, the noise level most evidenced inside the nursery was between 62.7 and $65.7 \mathrm{~dB}$, whose frequencies were $33.3 \%$ for the morning period and $25.4 \%$ for the afternoon period.

The values found in this study are lower than the maximum recommended value for pig farming $(85.0 \mathrm{~dB})$ (Moura \& Sarubbi, 2009). Noise level below this value does not harm the animal's welfare (Tolon et al., 2010). 


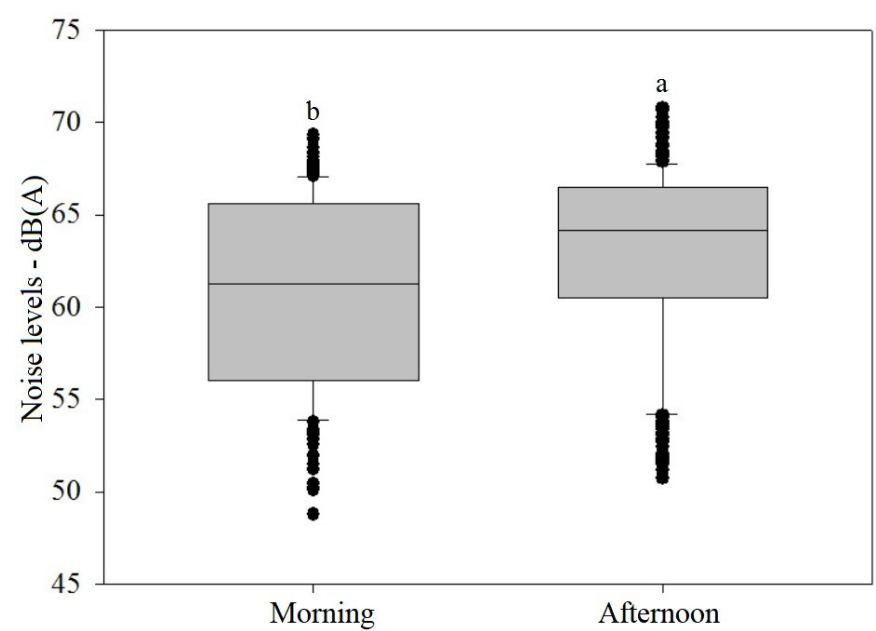

*Averages followed by at least one same letter among days of birth for each shed, do not differ among themselves by the Tukey test at 0.05 probability

Figure 3. Graphical representations of the average noise level for the morning and afternoon periods

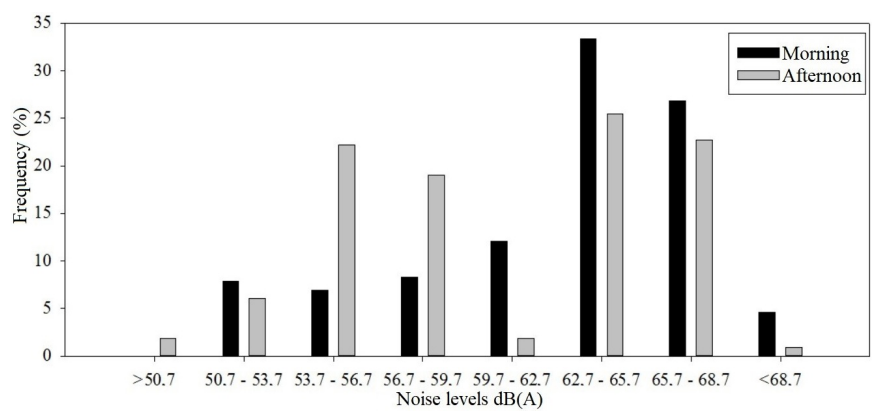

Figure 4. Graphical representations of frequencies (\%) of the noise level inside the nursery for the morning and afternoon periods

\section{Conclusions}

1. The dry-bulb temperature $\left(\mathrm{T}_{\mathrm{db}}\right)$, relative humidity $(\mathrm{RH})$ and black globe humidity index (BGHI) values remained outside the thermal comfort condition; therefore, the nursery ambience condition (inside the bay) does not provide comfort to piglets.

2. The analysis of spatial variability of noise levels inside the nursery, allowed the identification of specific areas where the noise levels are above the recommended temperature for animal's thermal comfort. Highest noise levels were observed for the suckling period of piglets, in places near the bays and near the air conditioning system.

\section{ACKNOWLEDGEMENTS}

The authors thank CAPES, CNPq and FAPEMIG for the financial support to the project.

\section{Literature Cited}

Amare, D.; Endalew, W. Agricultural mechanization: Assessment of mechanization impact experiences on the rural population and the implications for Ethiopian smallholders. Engineering and Applied Sciences, v.1, p.39-48, 2016.
Bachmaier, M.; Backers, M. Variogram or semivariogram? Variance or semivariance? Allan variance or introducing a new term? Mathematical Geosciences, v.43, p.735-740, 2011. https://doi. org/10.1007/s11004-011-9348-3

Baracho, M. S.; Tolon, Y. B.; Nääs, I. A.; Rojas, M. Sazonalidade da ambiência térmica, aérea e acústica em creche e terminação de suínos. Revista Brasileira de Engenharia de Biossistemas, v.2, p.201212, 2008. https://doi.org/10.18011/bioeng2008v2n3p201-212

Borges, G.; Miranda, K. O. S.; Rodriges, V. C.; Risi, N. Uso da geoestatística para avaliar a captação automática dos níveis de pressão sonora em instalações de creche para suínos. Engenharia Agrícola, v.30, p.377-385, 2010. https://doi.org/10.1590/S010069162010000300002

Budiño, F. E. L.; Vieira, R. F. N.; Mello, S. P.; Duarte, K. M. R. Behavior and performance of sows fed different levels of fiber and reared in individual cages or collective pens. Anais da Academia Brasileira de Ciências, v.86, p.2109-2119, 2014. https://doi. org/10.1590/0001-3765201420140301

Buffington, D. E.; Collazo-Arocho, A.; Canton, G. Black globe humidity index (BGHI) as a comfort equation for dairy cows. Transactions of the American Society of Agricultural Engineers, v.24, p.711-714, 1981. https://doi.org/10.13031/2013.34325

Castro, J. O.; Campos, A. T.; Ferreira, R. A.; Yanagi Junior, T.; Tadeu, H. C. Uso de ardósia na construção de celas de maternidade para suínos: II - Ambiente térmico e avaliação dos ruídos. Engenharia Agrícola, v.33, p.37-45, 2013. https://doi.org/10.1590/S010069162013000100005

Cecchin, D.; Campos, A. T.; Cruz, V. F.; Amaral, P. I.; Freitas, L. C. S. R.; Andrade, R. R. Thermal environment in growing and finishing pig facilities of different building typologies. Journal of Animal Behaviour and Biometeorology, v.5, p.118-123, 2017. https://doi. org/10.31893/2318-1265jabb.v5n4p118-123

Moura, D. J.; Sarubi, J. Interação entre ambiência e produtividade na suinocultura industrial: Realidade brasileira e as exigências internacionais. Suinocultura Industrial, v.220, p.28-33, 2009.

Ribeiro Junior, P. J.; Diggle, P. J. GeoR: A package for geostatistical analysis. R-News, v.1, p.14-18, 2001.

SAS Institute. SAS/STAT 9.22 user's guide what's new in SAS/STAT 9.22. Cary: SAS Institute, 2010. 20p. Book Excerpt

Seidel, E. J.; Oliveira, M. S. de. A classification for a geostatistical index of spatial dependence. Revista Brasileira de Ciência do Solo, v.40, p.1-10, 2016. https://doi.org/10.1590/18069657rbcs20160007

Sousa, N. C.; Nascimento, J. A. C.; Moreira, G. C.; Fagundes, J. F.; Damasceno, F. A.; Schiassi, L. Análise de desempenho de um protótipo de aquecedor de água solar para aquecimento de piso usando materiais alternativos. In: Congresso Mineiro de Engenharia e Tecnologia, 1, 2015, Lavras. Anais... Lavras: UFLADEG, 2015. p.72-80.

Tolon, Y. B.; Barracho, M. S.; Nääs, I. A.; Rojas, M.; Moura, D. J. Ambiências térmica, aérea e acústica para reprodutores suínos. Engenharia Agrícola, v.30, p.1-13, 2010. https://doi.org/10.1590/ S0100-69162010000100001

Yamamoto, J. K.; Landim, P. M. B. Geoestatística: Conceitos e aplicações. 1.ed. São Paulo: Editora Oficina de Textos, 2013. 215p. 